\author{
Marek Jaskólski \\ Doktorant \\ Zakład Geomorfologii, \\ Uniwersytet Wrocławski \\ marek.jaskolski@uwr.edu.pl
}

DOI: 10.35117/A_ENG_18_02_01

\title{
Spatial development and transport accessibility in Wroclaw suburbs, for example Siechnice, Smolec and Długołęka
}

\begin{abstract}
Suburbanization affects on spatial planning and transport policy in urban areas. The main theme of this report is to show how the transport network react to the chaotic and dynamic growth of suburban areas. Authors show spatial growth on three examples. The paper also tries to prove that with the growing trend toward suburbanization, more effective transportation systems must be developed to meet the needs of the low-density, suburban population. Authors refer to the process of suburbanization onexamples from Wroclaw and the surrounding locality.
\end{abstract}

Keywords: City transport; Suburbanization; Communication failure

\section{Introduction}

The article deals with three research issues: 1. spatial development of the seat of communes: Siechnice and Długołęka and housing estates in the municipality of Kąty WrocławskieSmolec; 2. an offer of public transport on the Wrocław route - surveyed units; 3. communication management in a communal approach (Fig. 1).In all neighboring districts of Wrocław, the motorisation index exceeded 500 vehicles / 1000 people, while the average value of this indicator in the country scale is 486 [3]. Automotive indices of districts allow noticing that there is no relation between the quality of the public transport offer (casus of Wrocław district, which theoretically should be penetrated to a large extent by public transport) and the attractiveness of individual transport. In many places during rush hour, the road load is equal to its capacity.

One of the direct effects of the city's sprawl and the development of the city's bedrooms is the rapid increase in the so-called traffic inclusions, i.e. places where local (or even strictly urban) traffic mixes with the regional and long-distance traffic. Road congestion also causes measurable financial losses (valued in 2014 at PLN 3.034 for costs per driver [3]) and constitute one of the most important (perhaps fundamental in the face of contemporary urbanization changes) barriers to urban development [2,5]. One of the worst scenarios in the development of the agglomeration is the discrepancy between the growing demand for passenger transport and the inefficiency of organizational supply. According to the Delloite report [3], delays caused by traffic jams in Wrocław have been rising since 2011, especially in the morning and afternoon rush hours.

The observation units were selected on the basis of their location and the scale of suburbanization. All three villages have the characteristics of a "Wroclaw's bedroom" which is the target and generator of traffic in the so-called daily migration, are located a short 
distance: $18.5 \mathrm{~km}$ - Długołęka, $12.6 \mathrm{~km}$ - Smolec, $13.8 \mathrm{~km}$ - Siechnice from the Wrocław market. They are located on priority road and railway communication routes. 


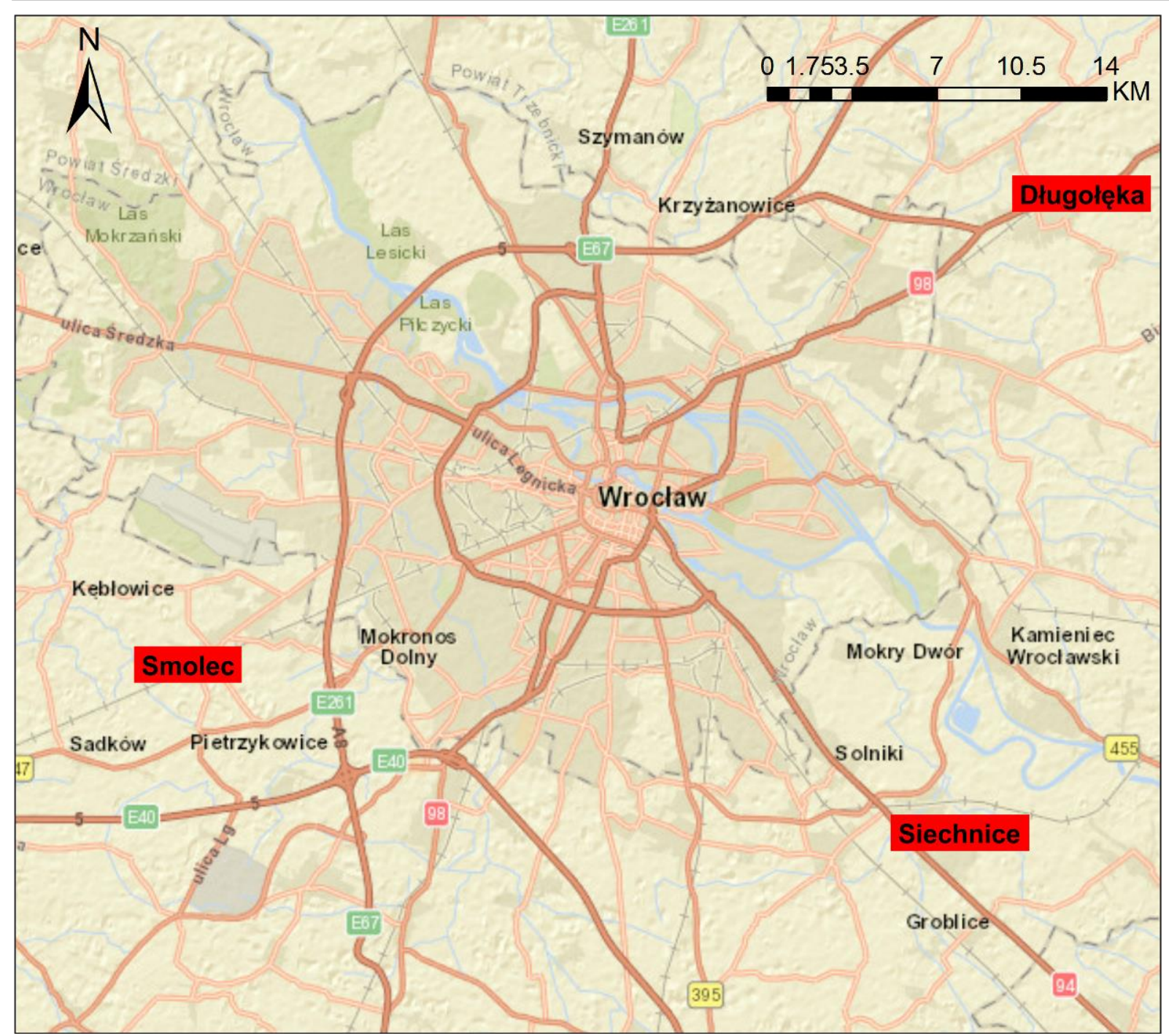

1. Location of the analyzed cities Source: own work based on the Word Street Map

\section{Spatial development of the Wroclaw suburbs}

The scale of extension of the Wrocław suburbs is relatively large and spatially extensive (fig. 4, 5, 6). A common feature of the analyzed cities is the chaotic (not concentrated) development of built-up areas, resulting in the uneconomic use of the investment space. Due to the availability and aggregation of data, including information on the population (Fig. 2) and new apartments completed for use (Fig. 3), the analysis was carried out at the municipal level (Długołęka, Smolec-Kąty Wrocławskie, Siechnice).

Analyzing data on the number of population in the years 1997-2015 (Fig. 2), one can notice an unambiguous, constant upward trend. The highest increase expressed in absolute numbers was characteristic of the Długołęka commune, in which 9643 inhabitants came, while the largest increase was found in Siechnice, where since 1997 the number of inhabitants has increased by over $100 \%$. The data on the number of flats in new buildings put into operation is important for the analysis. The commune with the highest values of this indicator is Długołęka, wherein 2008-2015 2693 apartments were handed over (in Siechnice 1271, and in Kąty Wrocławskie 1271). Therefore, Długołęka can be described as the leading direction of the Wrocław suburbanization in the analyzed spatial and temporal scope (Fig. 3).

The query of planning documents $[6,7,8,9]$ of the analyzed areas allows to state that in each of the analyzed cases the actual number of inhabitants significantly exceeded the originally forecasted values. This is an argument confirming the spontaneity of the suburbanization process as a process not controlled by self-government bodies. There is 
visible scattering and dispersion of buildings created after 1992 (Fig. 4,5,6). The advantage of landscaping located outside the center of the city is clearly visible. The effect of this unstoppable and irregular investment of the area is above all unnecessary extension and fragmentation of the communication network and utilities (water supply, sewage and energy infrastructure). The effect of this is inefficiency and underinvestment of communication and technical infrastructure. This leads to a situation in which newly built residential buildings for a period of time and for many years remain without access to paved and illuminated roads [1]. From the perspective of the efficiency of the communication service, a notoriously repeated error is increasing the direct connections of internal roads to higher-order roads (e.g. coroner, national and provincial) without indirectly linking the traffic through the collective road.

After 1992, the number of sub-internal roads connections in Siechnice was increased 10 connections of the internal road to the national road No. 94, Długołęka - 6 connections of the internal road to the national road No. 8 and Smolec - 6 connections of the internal road of the voivodeship road No. 370 (Figure 4, 5, 6). There is a lack of collective class roads, connecting residential and private internal roads into one network, and escaping them with one connection to higher-order roads. The effect of this is to reduce the capacity of higherorder roads (speed limits caused by numerous intersections).

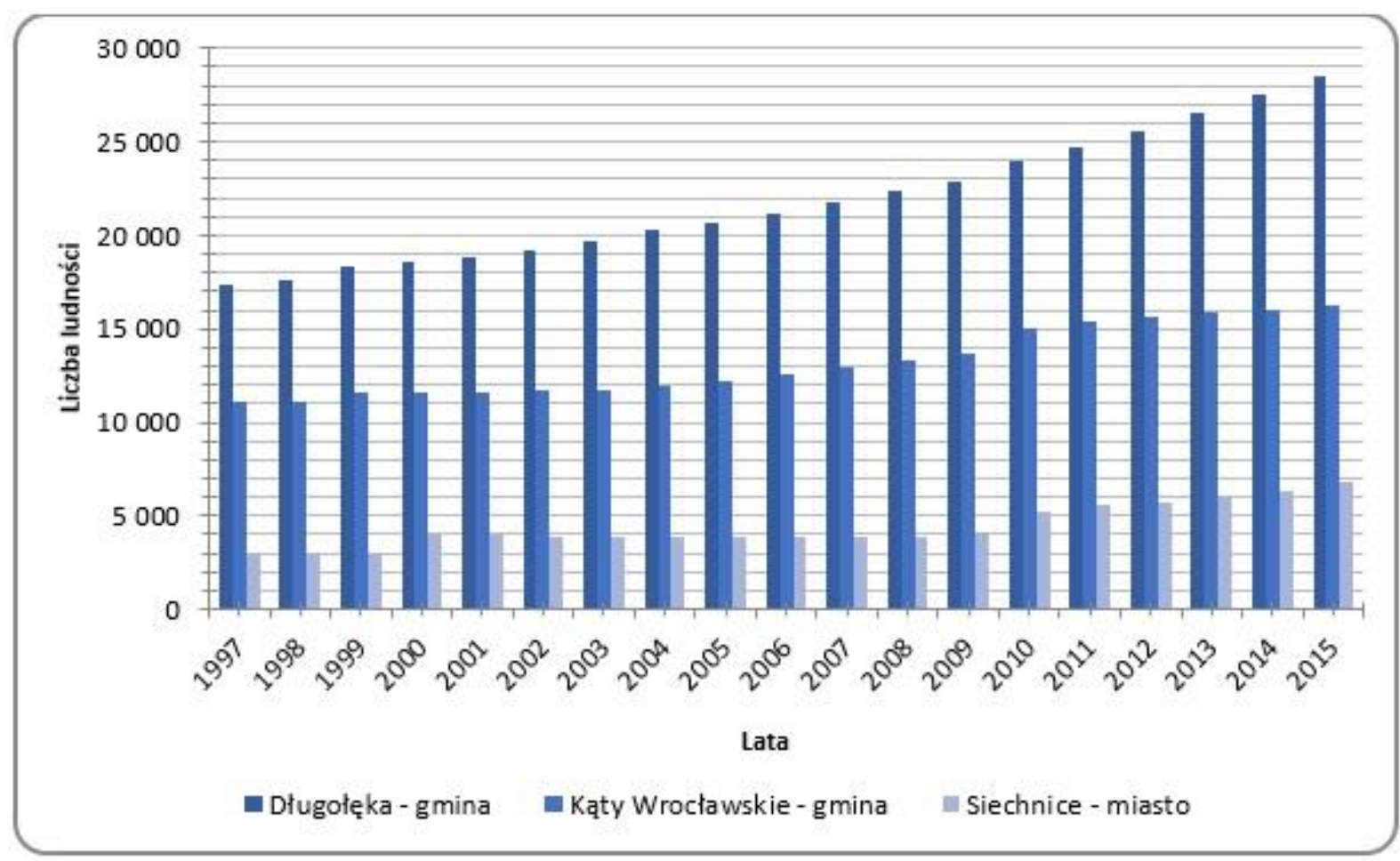

2. Population in the years 1997-2015. Source: own work based on GUS data 


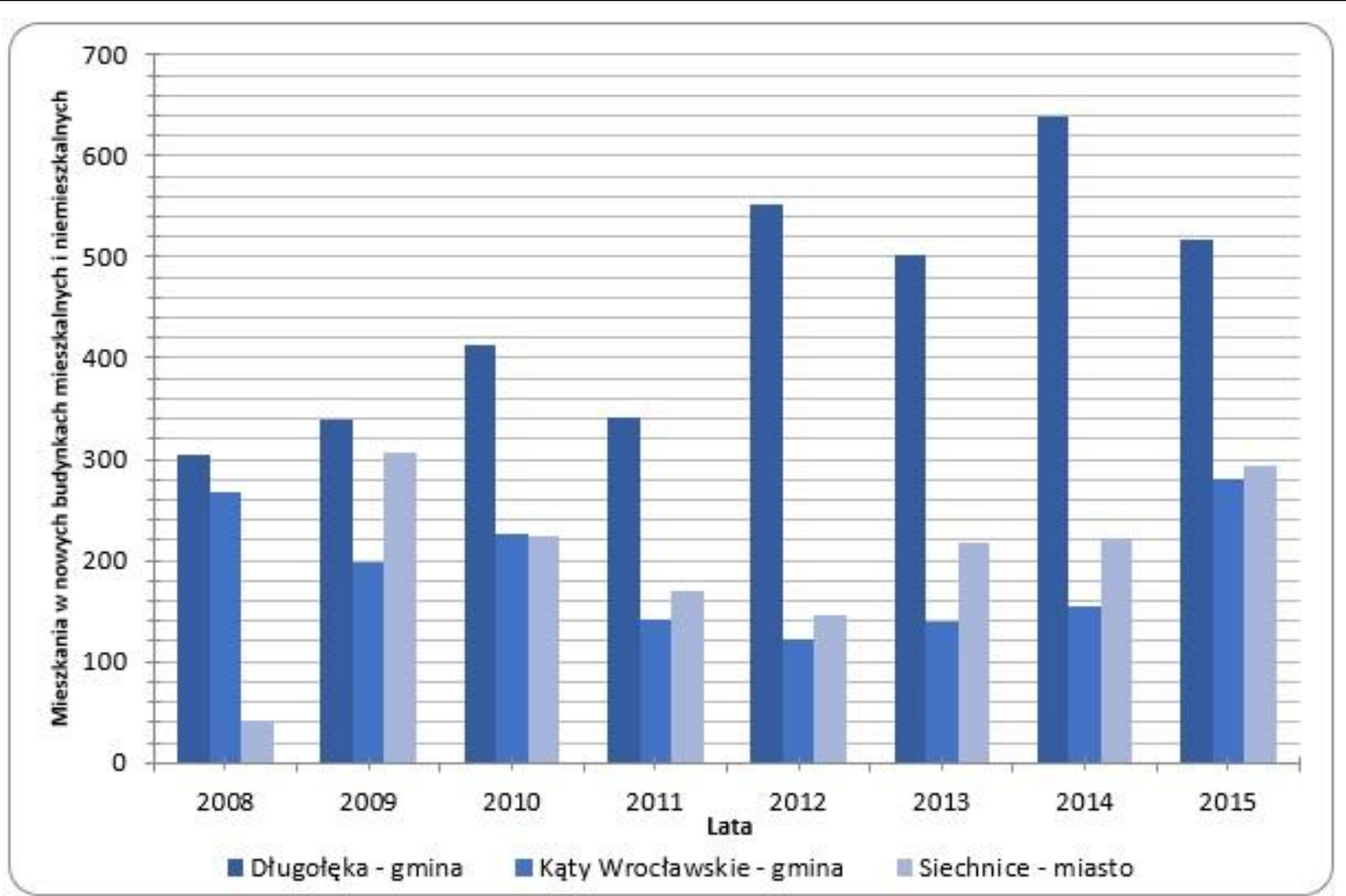

3. Apartments in new residential and non-residential buildings commissioned for use in 20082015. Source: own work based on GUS data

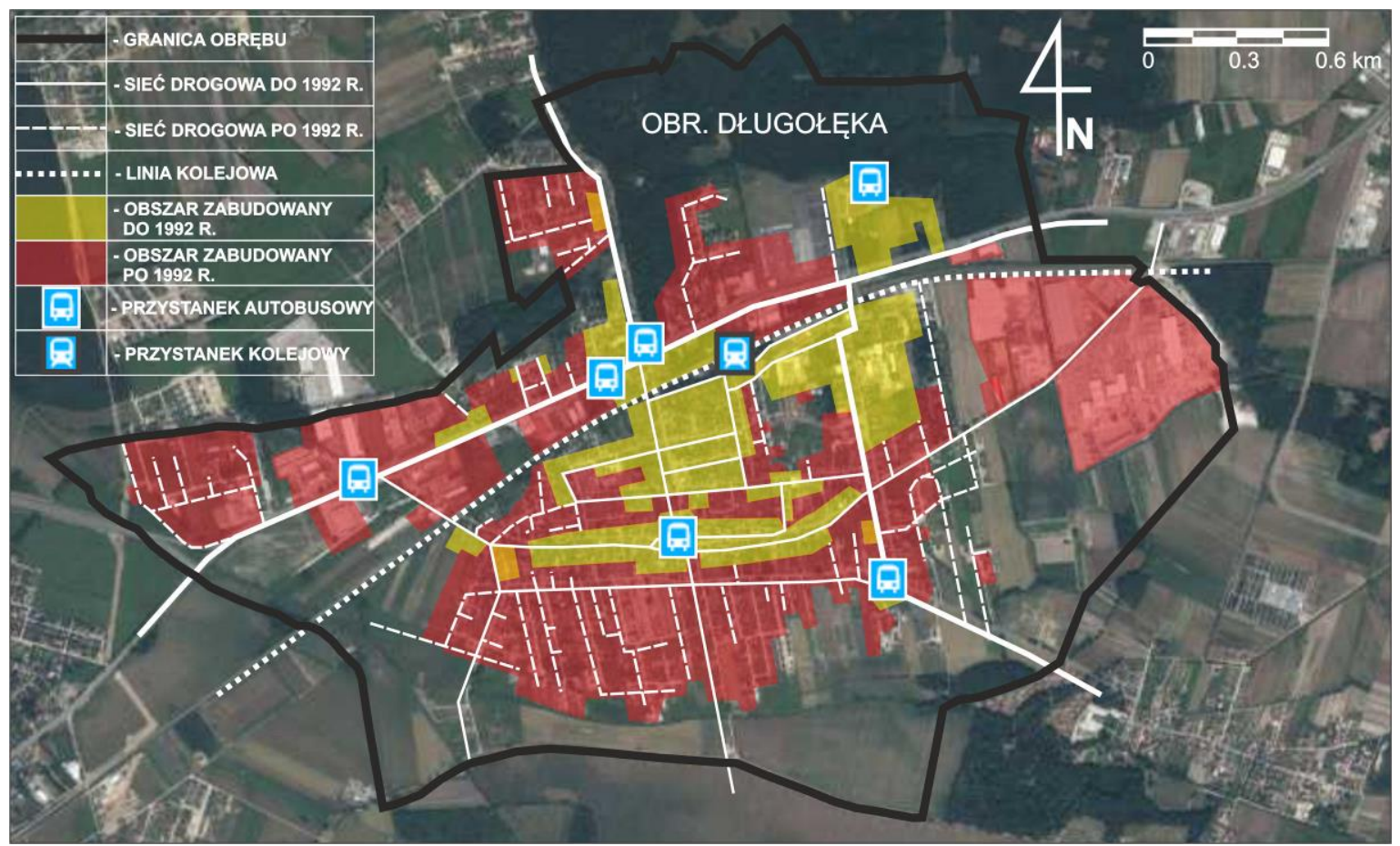

4. Development of buildings in Długołęka precinct in the years 1992-2015. Source: own work based on data: geoportal.gov.pl and wrosip.pl 


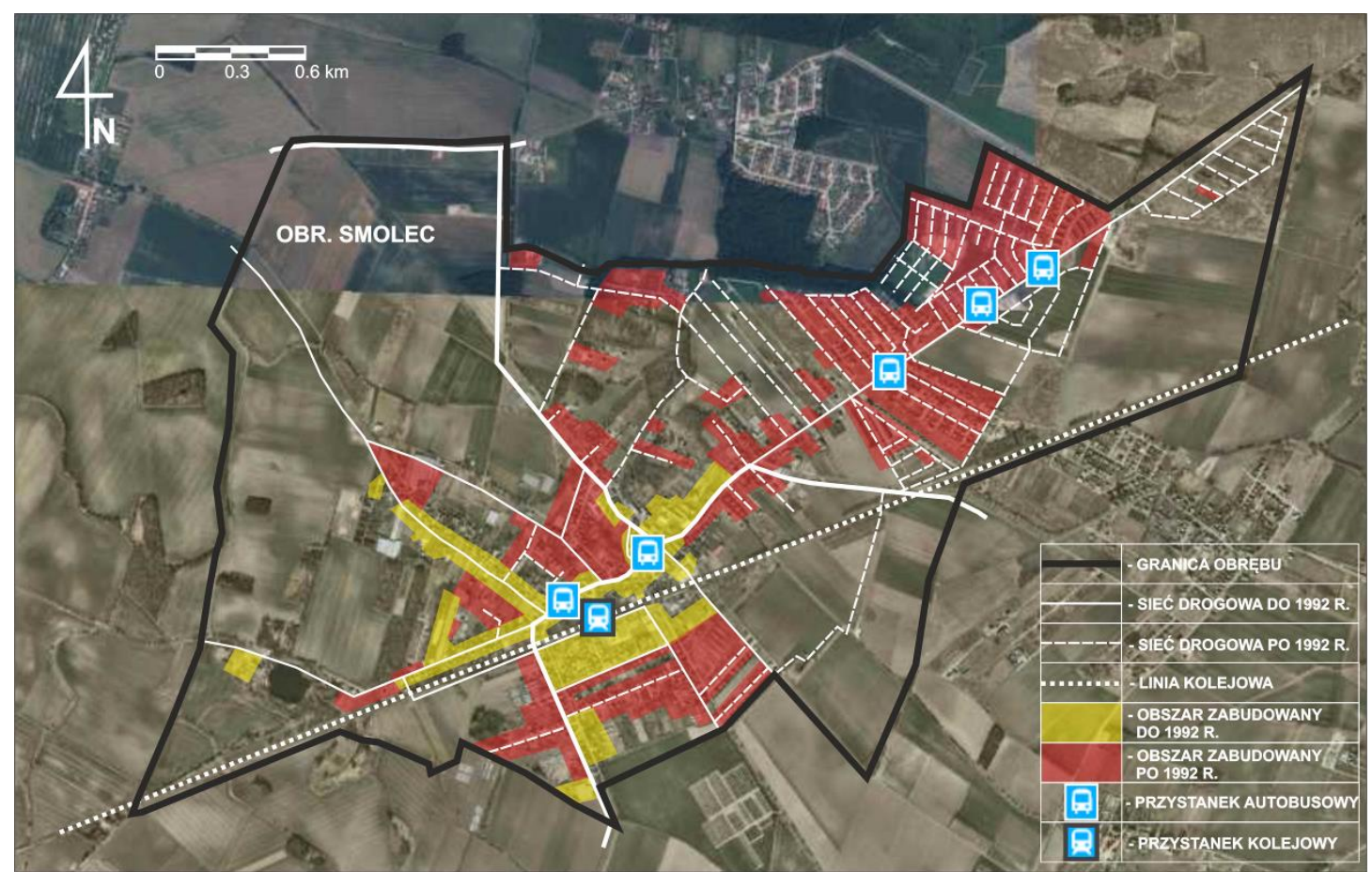

5. Development of buildings in Smolec precinct in the years 1992-2015. Source: own work based on data: geoportal.Gov.pl and wrosip.pl

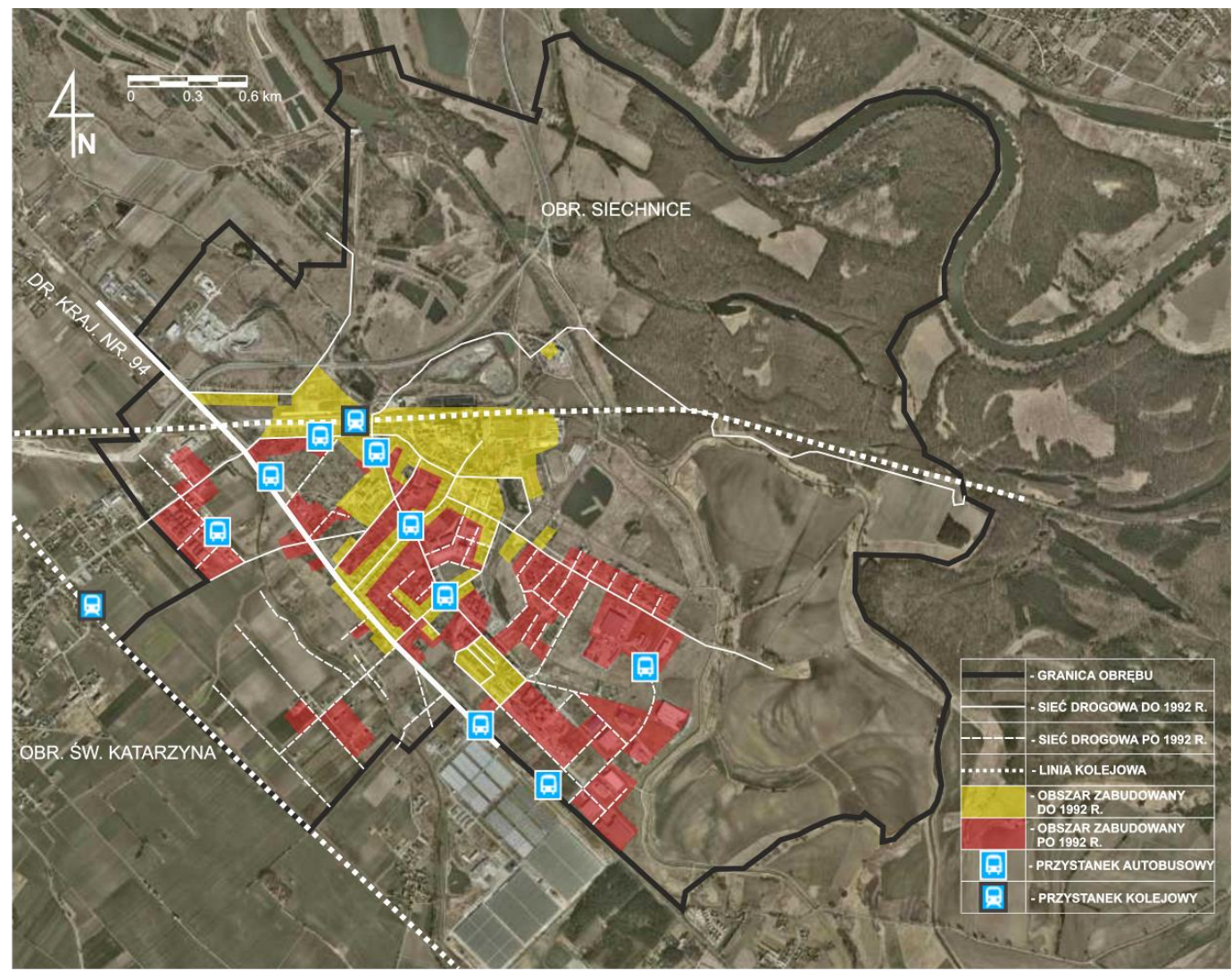

6. Development of buildings Siechnice precinct in the years 1992-2015. Source: own work based on data: geoportal.Gov.pl and wrosip.pl 


\section{Transport accessibility of the analyzed cities}

An important element in the field of spatial planning as part of providing communication services at an appropriate level is the striving for the location of a new housing development in the vicinity of bus and railway stops. In the case of the Wrocław Agglomeration Railway and further increase in the importance of agglomeration transport, the proximity of the bus stop (within the range of 500-800 m) will be a factor that may affect the growth of the number of potential passengers. Therefore, it would be necessary to prioritize compacting of housing in the vicinity of railway stations. Unfortunately, nowadays the noticeable trend of planning housing investments is reversed and conditioned primarily by land prices. Particularly intense distances from the railway station are visible in the case of Siechnice and Smolca. To some extent, it may be a historical location of the station on the outskirts of the village. In the case of Długołęka, the station is located in the center of the village and is well accessible from newly built housing estates.

In the analyzed cities, the offer of public transport presents itself at a diversified level (tab. 1). The possibility of getting public transport to the center of a larger unit (in this case, Wrocław) is one of the methods of public transport research [4].

Siechnice is located on the national road No. 94, connecting Wrocław with Oława and on the route of the railway line connecting Wrocław with Opole. The offer within the rail transport is carried out by 16 pairs of connections made by Koleje Dolnośląskie. The railway station is located in the northern part of the city. No long-distance trains run through the stations. Travel time by train from Wrocław (Wrocław Główny station) is about 10 minutes, compared to the travel time by car (about 30 minutes during rush hour) it is much shorter. Bus transport in terms of the number of connections is at a definitely higher level; during the working day, there are 127 courses in the direction of Wrocław. In the majority of cases, these are two types of connections: regional routes run on the Wrocław-Siechnice-Oława route and local ones connecting Siechnice with Wrocław using suburban transport. The first of them are made by the following companies: Beskid and PKS Oława. Public transport, in turn, is the responsibility of a consortium of companies Sevibus and DLA that operates 3 normal lines running from Siechnice towards the very center of Wrocław. In addition, the offer is supplemented by 4 courses of the 920 feed line on the route Zębice- Św. Katarzyna PKPKotowice accomplished by minibuses. The average travel time from the center of Wrocław (Dominikański Square and Main Railway Station) oscilates within 19 - 35 minutes depending on the place of departure and time of day. An important element affecting the quality of suburban communication is a large degree of penetration of the commune of Siechnice and the possibility of getting to the very center of Wrocław. You should also pay attention to the night courses served by the $900 \mathrm{~L}$ line at 00.45 from Dominikański Square in the direction of Siechnice.

Smolec is located south-west of Wrocław in the municipality of Kąty Wrocławskie. The main road running through the village is the national road no. 370 (Smolec - Mokronos Górny). In addition, a railway line No. 274 (Wrocław Świebodzki- Jaworzyna Śląska- Jelenia Góra- Zgorzelec). Railway transport is carried out through 22 courses per day (WrocławSmolec-Wałbrzych-Jelenia Góra-Szklarska Poręba Górna and Wrocław-Jaworzyna ŚląskaDzierżoniów Śląski courses, implemented by Koleje Dolnośląskie and Przewozy Regionalne). In most cases, traction support is the newly purchased Newag Impuls traction units (3 and 4 segments). Rapid trains pass through the village, but without commercial stops. The railway line in Smolec divides the village into a smaller southern part and a much larger northern one (in which most of the new construction is located, including large development estates). One of the barriers to encouraging residents to rail transport is the distance from the railway station to the emerging large housing estates (up to $2.5 \mathrm{~km}$ ). The travel time from Wroclaw to Smolec by train oscillates within 12-14 minutes. 
Bus transport is carried out through 2 suburban lines: 507, 577 and Wrocław-SmolecUdanin courses. On a working day, 26 bus journeys are carried out, the driving time (center of Wrocław) is about 20-26 minutes. Lines 507 and 577 do not commute in Wrocław to the city center, they finish the course at the level of pl. Legions (about $3 \mathrm{~km}$ to the Market Square). However, the connections between Wrocław and Udanin are going directly to the bus stop at Dawida Street. There are 5 bus stops in Smolec. In the case of travel from Wrockaw to Smolec, using the car is the most time-consuming (about 35 minutes drive).

Długolęka is the seat of the commune with the same name and is located northeast of Wrocław along the national road. Before the construction of the Wrocław Motorway Bypass (AOW), the national road No. 8 towards Piotrków Trybunalski; after the opening of the AOW, the road was degraded to a lower category and Długołęka obtained a direct road connection with the AOW through a road link (road S8). The railway line No. 143 (Wrocław Mikołajów - Oleśnica - Kalety). Railway transport to Długołęka is carried out only by Regio trains of Przewozy Regionalne. During the business day, it is 19 courses from Wrocław towards Lubliniec, Oleśnica and Ostrów Wielkopolski. The driving time is around 29-32 minutes. The station is located close to residential buildings and about 100 meters from the main road. Despite the rapid trains passing through the station, none of them carries out a commercial stop in Długołęka. Bus transport from Wrocław to Długołęka is carried out by the Sevibus consortium (3 suburban lines: 914, 944 and 904). In addition, the offer includes other bus companies running, among others to Oleśnica, Syców and Ostrzeszów. During the working day, the number of bus journeys is at the level of 110 a day. Cruising rates stop at stops located on the main road, while communal (local) transport reaches 6 stops in Długołęka. All flight prices start at PKS PKS in Wrocław (Sucha Street), while lines 904 and 914 from Dominikański Square. Line 944 is a typical delivery line and ends the course on one of the peripheral neighborhoods of Wrockaw - Psie Pole (near the railway station). Depending on the initial stop, access by bus to Długołęka takes about 23-40 minutes. Traveling by car, as in the case of other examples discussed, takes between 23-30 minutes.

In summary, the offer of public transport in the described cities is diverse (table 1,2) while the driving time is very approximate and oscillates in the range of 30-35 minutes of driving. In each case, the bus offer largely exceeds the railway offer in terms of the number of courses (the difference for Siechnice is 111 bus routes more than railway connections in the same period, Długołęka - 91 courses, Smolec - 4 courses). In terms of the number of bus connections, the worst situation is in the service of Smolec (26 connections), in both cities the number of trips is almost 5 times higher. The maximum number of railway connections is in Smolec. As part of rail transport, the diversity of the offer is definitely less visible (from 16 courses in Siechnice to 22 in Smolec). Taking into account the level of transport development in communes, the largest number of bus stops is located in the commune of Długołęka (96), the next in terms of their number is the municipality of Kąty Wrocławskie (33). The next relative indicator that reflects the degree of utilization and development of transport is the number of bus stops with respect to the surface. In this case, the highest density is visible in the commune. Długołęka $(0,45)$ and Siechnice $(0,41)$. In this respect, the commune of Kąty Wrocławskie stands out visibly; the indicator, in this case, is 0,19 , which translates into low availability to stops. In terms of demographic potential (referring to the population in the commune), the best situation is in the commune of Długołęka $(3,37)$. The lowest values are found in the commune of Kąty Wrocławskie $(1,44)$. It is a commune in which there is the largest shortage of bus stops in the spatial and demographic aspect. On the other hand, as part of the average number of departing courses from one stop in the municipality of Katy Wrocławskie, it shows the highest values (24 per day). This is an example of a high accumulation of a bus offer on a small number of stops. 
Tab.1. Travel time from the center of Wroclaw to the discussed cities

\begin{tabular}{|l|l|l|l|l|l|}
\hline $\begin{array}{l}\text { Access road } \\
\text { from } \\
\text { Wroclaw to: }\end{array}$ & $\begin{array}{l}\text { Car (min- } \\
\text { max) }\end{array}$ & $\begin{array}{l}\text { Railway } \\
\text { (min) }\end{array}$ & $\begin{array}{l}\text { Number of } \\
\text { railway } \\
\text { connections }\end{array}$ & $\begin{array}{l}\text { Bus } \\
\text { (min) }\end{array}$ & $\begin{array}{l}\text { Number of bus } \\
\text { connections }\end{array}$ \\
\hline Siechnic & $25-30$ & $10-11$ & 16 & $19-35$ & 127 \\
\hline Długołęki & $23-30$ & $29-32$ & 19 & $23-40$ & 110 \\
\hline Smolca & $30-36$ & $12-14$ & 22 & $20-26$ & 26 \\
\hline
\end{tabular}

Source: own work (as at 12/12/2016)

Tab. 2. Degree of transport development in communes

\begin{tabular}{|c|c|c|c|}
\hline & Siechnice & Kąty Wroclawskie & Długołęka \\
\hline \multicolumn{4}{|l|}{ Indicator } \\
\hline 1. Population & 19819 & 22910 & 28501 \\
\hline $\begin{array}{l}\text { 2. Surface area of } \\
\text { the commune }\left[\mathrm{km}^{2}\right]\end{array}$ & 99 & 177 & 213 \\
\hline $\begin{array}{l}\text { 3. The sum of bus } \\
\text { stops in the } \\
\text { commune }\end{array}$ & 41 & 33 & 96 \\
\hline $\begin{array}{l}\text { 4. Number of stops } \\
/ \mathrm{km}^{2}\end{array}$ & 0,41 & 0,19 & 0,45 \\
\hline $\begin{array}{l}\text { 5. Number of stops / } \\
1000 \text { os. }\end{array}$ & 2,07 & 1,44 & 3,37 \\
\hline $\begin{array}{l}\text { 6. The average } \\
\text { number of courses } \\
\text { from the bus stop }\end{array}$ & 15 & 24 & 14 \\
\hline
\end{tabular}

Source: own work based on transporters' data

\section{Summary}

The main cause of the communication congestion problem is the irrational use of space. The necessary step to change this negative trend is the commencement of macro-scale and comprehensive spatial planning, taking into account all aspects of urban planning [2]. From the formal and legal perspective [10], the current legislation favors the deepening of communication chaos, through the possibility of issuing building permits based on the decision on building conditions, in which the condition of access to the public road and the basic media must be met. A particularly negative phenomenon may be the lowering of the standard of living of suburban residents resulting from the significant elongation of travel time and ride comfort [1], which on the discussed lines is relatively high due to the low-floor and low-entry low-entry transport. That is why one should strive to shorten the travel time (scheduled and actual) and to eliminate possible delays in running public transport. According to the authors of this study, the issue of organizing public transport is all the more important as it is a response to the increase in human mobility.

\section{Source materials}

[1] Kajdanek K., Suburbanizacja po polsku; Zakład Wydawniczy Nomos 2013

[2] Markowski, T. Marszał, Metropolie, obszary metropolitalne, metropolizacja. Problemy i pojęcia podstawowe, Warszawa 2006, s. 12. 
[3] Raport Deloitte, Raport o korkach w 7 największych miastach Polski; Deloitte, 2012.

[4] Soczówka A., Zróżnicowanie struktury przestrzennej komunikacji miejskiej w konurbacji katowickiej; Wydział Nauk o Ziemi Uniwersytetu Śląskiego; 2012.

[5] Starowicz W., Koncepcja rozwoju transportu publicznego w miastach; Kraków, 2010; s.31-35.

[6] Strategia rozwoju powiatu wrocławskiego na lata $2012-2020$.

[7] Studium uwarunkowań i kierunków zagospodarowania przestrzennego gminy Kąty Wrocławskie.

[8] Studium uwarunkowań i kierunków zagospodarowania przestrzennego gminy Długołęka.

[9] Studium uwarunkowań i kierunków zagospodarowania przestrzennego gminy Siechnice.

[10] Ustawa z dnia 27 marca 2003 r. O planowaniu i zagospodarowaniu przestrzennym. 